\title{
Developments of an Emerging Infectious Agent: Norovirus
}

\author{
Manikant Tripathi ${ }^{1}$ and Shailendra Kumar ${ }^{1^{*}}$ \\ ${ }^{1}$ Centre of Excellence, DST-FIST Supported Department of Microbiology, Dr. Rammanohar Lohia \\ Avadh University, Ayodhya-224001, U.P., India.
}

\begin{abstract}
Authors' contributions
This work was carried out in collaboration between both the authors. Author MT designed the review article, collected literature information and wrote the first draft of manuscript. Author SK read the draft and incorporated basic facts and corrected the manuscript. Both the authors read and approved the final manuscript.

Article Information

DOI: 10.9734/ARRB/2019/v31i430054 Editor(s):

(1) Dr. George Perry, Dean and Professor of Biology, University of Texas at San Antonio, USA.

Reviewers:

(1) Gabor Ternak, University of Pecs, Hungary. (2) K. Ramesh Kumar, S.V.S. Medical College, India. (3) A. Shaikh Amir, Savitribai Phule Pune University, India. Complete Peer review History: http://www.sdiarticle3.com/review-history/48077
\end{abstract}

Review Article

Received 20 December 2018

Accepted 19 March 2019

Published 01 April 2019

\section{ABSTRACT}

Norovirus, a member of calciviruses family is the leading cause of community-acquired and nosocomial acute gastroenteritis or inflammation of the stomach and intestine. This pathogenic virus is highly communicable and found in the stools and vomit of infected persons. The symptoms of infection include sudden vomiting, diarrhea, abdominal cramp, headache, low grade fever, nausea, chills, etc. This RNA virus spreads through contaminated foods or liquids, sharing norovirus loaded objects and contact with infection individual. There is neither a specific medicine nor vaccination available for norovirus infection. Some vaccines are under pre-clinical trials. However, the virus can be controlled by following good personal hygiene practices such as hand washing, eating properly washed fruits and vegetables, properly cooked foods, and cleaning of the area occupied by patient. Norovirus infection can be regulated through public awareness and dissemination of proper knowledge about this viral infection. The present review summarizes the biology of infections caused by norovirus and their control measures.

Keywords: Calciviruses; diarrhea; viral gastroenteritis; inflammation; norovirus.

${ }^{*}$ Corresponding author: E-mail: shailendra.microbio@gmail.com; 


\section{INTRODUCTION}

The diarrheal diseases are caused by both bacteria and virus. Norovirus is one of the highly infectious viral agents causing acute gastroenteritis with diarrhea and vomiting [1]. The gastroenteritis associated problem is a common cause of morbidity and mortality among people of all ages, it accounts for millions of deaths of children below the age of 5 years, worldwide [2,3]. It imposes incredible economic loss and social concern [4].

Norovirus is named after the place, from where it was reported for the first time, Norwalk, Ohio during 1968. The strains of norovirus have been associated with infections in several animals including human, cows, pigs and mice. As per an estimate of Centers for Disease Control and Prevention (CDC) approximately 19-21 million infections have been reported across the United States [5]. Globally, every year the virus causes acute gastroenteritis among 685 million people. Out of that about 200 million cases are reported in children below the age of 5 years. The illness is responsible for death of approximately 50000 children annually [6]. The illness is also known as food poisoning and stomach flu. It can result in frequent diarrhea and vomiting several times a day. Few people may get severely dehydrated due to diarrhea and vomiting, especially young children, the elderly, immunocompromised adults, and people with other illnesses $[5,7]$.

The outbreak of norovirus infection has been reported from different parts of world by several researchers [8-10]. The disease caused by norovirus is self-limiting but in several cases it is fatal resulting into death of infected person [11]. The commonest co-pathogen with norovirus infection is rotavius. A mild increase in norovirus infection is proportionally associated with diarrheal episodes during the summer season [12]. The mortality of patients create an alarming state of affairs, while lack of virus culture techniques limits its research and thereby knowledge about this virus around the world. There is no satisfactory therapy or commercial vaccine for noroviruses till date [13]. However, research on vaccine development for this viral infection is underway.

\section{STRUCTURE AND LIFE CYCLE}

It is a non-enveloped, single stranded positive sense RNA genome with icosahedral geometries. The capsid diameter may range between 23 to $40 \mathrm{~nm}$. The virus particle is an amorphous structure as observed electron microscopically [14]. Norovirus genomes contain three open reading frames (ORFs), first ORF encodes the structural capsid protein including RNA dependent RNA polymerase. Second ORF encodes the major capsid protein (VP1), and third ORF encodes a minor capsid protein (VP2) $[15,16]$.

The virus is divided into five genogroups (G-I to G-V) of which G-I, G-II and G-IV are known to cause acute gastroenteritis in human $[17,18]$. However, G-Il norovirus is the major genogroup that causes outbreaks and sporadic infections $[19,20]$. Additionally, the genetic diversity of norovirus and the emergence of new variants may help the virus to escape the immunity [14].

Ushijima et al. [14] discussed the life cycle of norovirus. Norovirus attaches to host cells using carbohydrate receptor and enters into the cells through clathrin and caveolin independent endocytosis (Fig. 1). Following attachment the virus is uncoated and viral genomic RNA is released into the cytoplasm. The proteins associated with viral genome are removed and viral RNA is translated into a processed polyprotein to yield the replication proteins. Double stranded RNA genome is synthesized from the positive sense SS RNA viral genome, which is further transcribed and replicated to yield viral mRNA and a new single stranded plus sense RNA genomes, respectively. Sub-genomic RNA is translated to form major capsid protein (VP1). Finally new virion particles are assembled and released by cell lysis [21,22].

\section{SYMPTOMS OF NOROVIRUS INFECTION}

The incubation period for the norovirus infection is about 24 to 48 hours. The primary symptoms of infection are appear with nausea, abdominal cramps, vomiting and diarrhea [23]. Other symptoms may include muscle-aches, headaches, tiredness and low grade fever. The symptoms generally last for one to three days. However, the duration of illness may vary with age of patients [24].

\section{TRANSMISSION}

The peak season for the norovirus infections are cold weather [25]. It requires very less infective dose, as little as 10 to 100 virion particles to initiate infection [5]. Primarily the virus follows faecal-oral route and is transmitted through contaminated water or food. It can also transmit 
through several other means such as direct contact with patient, droplets of vomit, and fomites (surfaces contaminated either with faeces or vomit) contaminated with norovirus. Fig. 2 shows the norovirus sources and type of settings affected by it $[5,16]$. The infection spreads mainly among the people in crowded and enclosed places such as, staying in hotels, resorts, nursing homes, cruise ships and the place with crowd of people (https://www.fortishealthcare.com). The probability of norovirus infections is increased among the people with compromised immune system, people following unhygienic practices. It has been reported that norovirus is the main cause of medically-attended gastroenteritis among non-deployed United States military members [26].
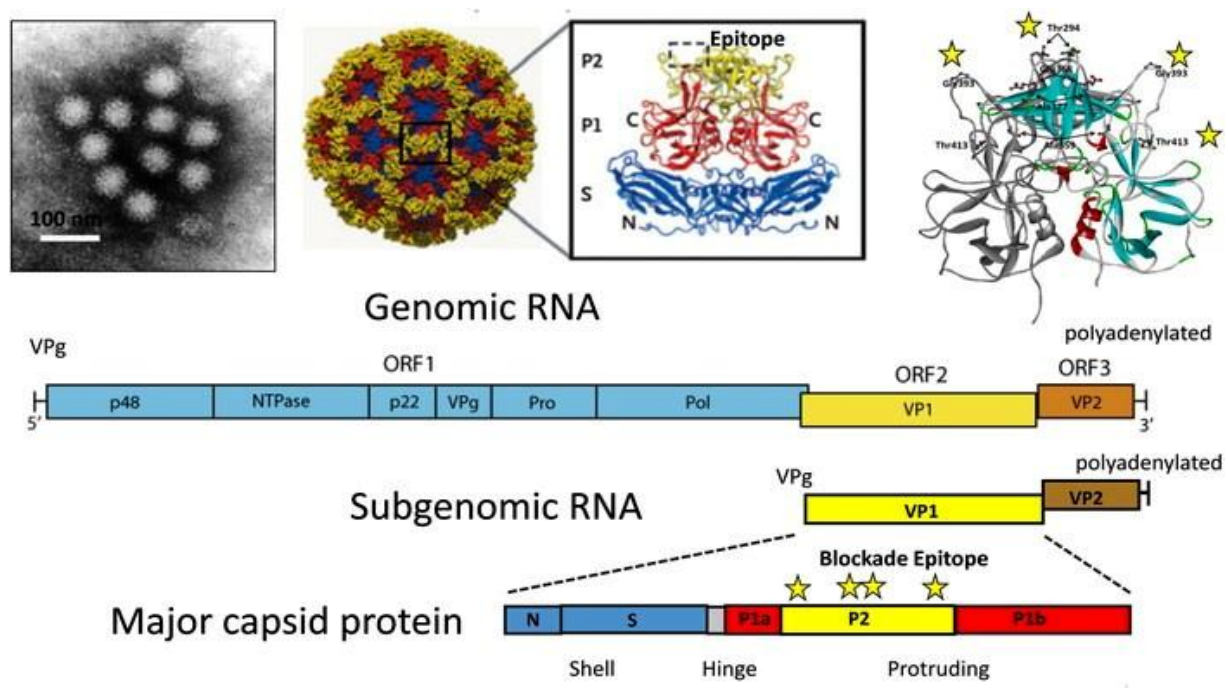

Fig. 1. Structure of norovirus by immune electron microscope (Source: Ushijima et al. [14])

(a) Setting for norovirus outbreak
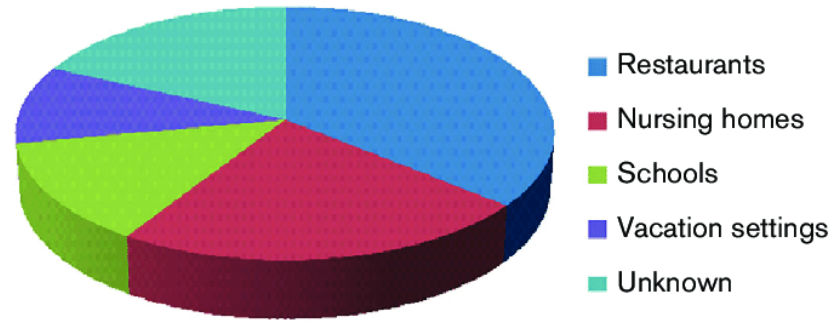

(b) Source of norovirus

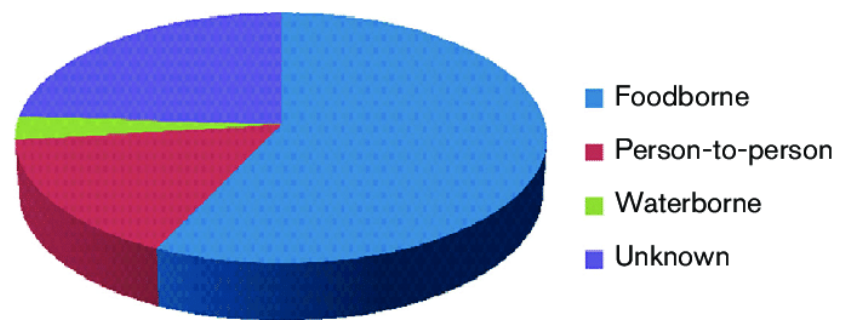

Fig. 2. Norovirus outbreak characteristics; data collected by Centre for Disease Control. The results of this surveillance, (a) for the source of norovirus, and (b) the type of setting affected by the outbreak

Source: http://www.cdc.gov/nicdod/dvrd/revb/gastro/norovirus-factsheet.htm, Karst [16] 
Norovirus infections have been reported from Asian countries also. Menon et al. [12] studied norovirus gastroenteritis in a birth cohort in Southern India. They studied the disease reinfection rates, strain prevalence and genetic susceptibility to norovirus in a birth cohort of 373 Indian children of age below two years. In this study, they analyzed stool samples from diarrhea and vomiting episodes for screening of norovirus. They reported that diarrheal infections in south India were associated with norovirus G-I, G-II and mixture of both. Menon et al. [12] also suggested further characterization of asymptomatic infections and immune response for proper understanding of norovirus infection and disease.

\section{PATHOGENESIS}

The norovirus infections are confirmed primarily on the basis of physical, histological, and biochemical observations of infected persons [16]. The infection develops the histological changes in intestinal mucosa such as broadening and blunting of villi, shortening of the microvilli, enlarged and pale mitochondria, increased cytoplasmic vacuolization, and intercellular edema [27-30]. The norovirus infections may also cause crypt cell hyperplasia [30,31]. An increased number of intraepithelial cytotoxic $T$ cells have been reported in the duodenum of infected person during 0-6 days after onset of symptoms [31]. However, the exact mechanism of norovirus dissemination to other organs is not understood properly, but it has been observed that the murine norovirus infect dendritic cells, which migrate from tissues to draining lymph nodes. Therefore, extra-intestinal spread of norovirus through migrant dendritic cells has been proposed [16].

\section{DIAGNOSIS}

Primarily the symptoms are analyzed for diagnosis of norovirus infection. Reverse transcription polymerase chain reaction (RTPCR) has been used as a common diagnostic test at state public health laboratories to detect the virus in stool specimens collected from patient (https:/www.cdc.com/norovirus). The diagnosis of virus is also based on reverse loop-mediated isothermal amplification (LAMP) and immune chromatography [14].

\section{TREATMENT AND PREVENTION}

Norovirus infection reports are increasing rapidly. Therefore, it's a need of hour to have specific treatment and prevention strategies. However, there is no specific anti-norovirus drug for the treatment. At present there are no vaccines for prevention of noroviruses infections. The vaccine development for prevention of norovirus infection is under progress [7]. Replenishment of lost water by drinking oral rehydration solution with plenty of water or through intravenous fluid replacement has been the main stay for survival.

Norovirus outbreaks can be controlled by restricting its dissemination and proliferation in environment. However, other preventive measures include good hygienic practices such as hand washing with warm running water and soap, avoidance of contaminated food and water, washing of fruits and vegetable before use, disinfection of virus contaminated areas and avoid travelling of infected until signs and symptoms

(https://www.fortishealthcare.com).

\section{CONCLUSIONS}

Despite availability of several antibacterial antibiotics, viral diseases remain a crucial global challenge. Several factors such as contaminated foods and water, crowded environments (children care centers, nursing homes, schools, etc.) spread norovirus infections. The virus has RNA genome, which is prone to frequent genetic change leading to high frequency of structural changes. The unavailability of vaccines and no specific drug limits the treatment strategies. Therefore, hygienic practices are the mainstay for prevention of norovirus infections. Spreading awareness and proper management of viral infection is essential to tackle the threat posed by norovirus and avoid national loss.

\section{COMPETING INTERESTS}

Authors have declared that no competing interests exist.

\section{REFERENCES}

1. Walker CLF, Perin J, Aryee MJ, BoschiPinto C, Black RE. Diarrhea incidence in low- and middle-income countries in 1990 and 2010: A systematic review. BMC Public Health. 2012;12:220.

2. Bryce J, Boschi-Pinto C, Shibuya K, Black RE. WHO estimates of the cause of death in children. Lancet. 2005;365:11471152. 
3. Ahmed SM, Hall AJ, Robinson AE, et al. Global prevalence of norovirus in cases of gastroenteritis: a systematic review and meta-analysis. Lancet Infect. Dis. 2014; 14:725-730.

4. White PA. Evolution of norovirus. Clin. Microbiol. Infect. 2014;20:741-745.

5. CDC; 2018.

Available:https://www.cdc.gov/norovirus/tre nds-outbreaks/burden-US.html

[Accessed on 10 February 2019]

6. CDC; 2018.

Available:https://www.cdc.gov/norovirus/tre nds-outbreaks/worldwide.html

[Accessed on 10 February 2019]

7. Alibadi N, Lopman BA, Parashar UD, Hall AJ. Progress towards norovirus vaccines: Consideration for further development and implementation in potential target populations. Expert Rev. Vaccines. 2015; 14:1241-1253.

8. Koo HL, Ajami NJ, Jiang JD, Neill FH, Atmar RL, Ericsson CD, et al. Norovirus as A cause of diarrhea in travelers to Gautemala, India, and Mexico. J. Clin. Microbiol. 2010;48:1673-1676.

9. Hall AJ, Vinje J, Lopman B, Park GW, Yen C, Gregoricus N, et al. Norovirus disease in the United States. Emerg. Infect. Dis. 2013;19:1198-1205

10. Patel MM, Widdowson MA, Glass RI, Akazawa K, Vinje J, Parashar UD. Systematic literature review of role of noroviruses in sporadic gastroenteritis. Emerg. Infect. Dis. 2008;14:12241231.

11. $\mathrm{Xu} \mathrm{C}, \mathrm{Fu} J$, Zhu Y. (A narrative review of norovirus gastroenteritis: more global attention is needed. Int. J. Travel Med. Glob. Health. 2016;4:101-106.

12. Menon VK, George S, Sarkar R, Giri S, et al. Norovirus gastroentertitis in a birth cohort in Southern India. PloS ONE 2016;11: e157007.

13. Tan $M$, Jiang $X$. Vaccine against norovirus. Hum. Vaccine Immunother. 2014;10:14491456.

14. Ushijima $H$, Fujimoto $T$, Müller WEG, Hayakawa S. Norovirus and foodborne disease: A review. Food Safety; 2014. DOI: 10.14252/foodsafetyfscj.2014027

15. Glass RI, Parashar UD, Estes MK. Norovirus gastroenteritis. N. Engl. J. Med. 2009;361:1776-1785.

16. Karst SM. Pathogenesis of norovirus, emerging RNA viruses. Viruses. 2010;2:748-781.
17. Knipe DMH, Peter M. Fields Virology. 5th ed. Philadelphia: Wolters Kluwer Health/Lippincott, Williams \& Wilkin; 2007.

18. Ramani S, Kang G. Viruses causing childhood diarrhoea in the developing world. Curr. Opin. Infect. Dis. 2009;22:477-482.

19. Monica B, Ramani S, Banerjee I, Primrose $\mathrm{B}$, Iturriza-Gomara $\mathrm{M}$, Gallimore $\mathrm{Cl}$, et al. Human caliciviruses in symptomatic and asymptomatic infections in children in Vellore, South India. J. Med. Virol. 2007;79:544-551.

20. O'Ryan ML, Lucero Y, Prado V, Santolaya, ME, Rabello M, Solis Y, et al. Symptomatic and asymptomatic rotavirus and norovirus infections during infancy in a Chilean birth cohort. Pediatr. Infect. Dis. J. 2009;28:879-884.

21. Ushijima $\mathrm{H}$, Okitsu $\mathrm{S}$, Khamrin $\mathrm{P}$. Calicivirus. Uirusu. 2011;61:193-203.

22. Viral Zone.

Available:http://viralzone.expasy.org/all_by species/294.html.

23. Patel M, Hall AJ, Vinje J, Parashar UD. Norovirus: A comprehensive review. J.Clin. Virol. 2009;44:1-8.

24. Rockx B, De Wit M, Vennema H, Vinje J, De Bruin $E$, et al. Natural history of human calcivirus infection: a prospective cohort study. Clin. Infect. Dis. 2002;35:246-253.

25. Mounts AW, Ando T, Koopmans M, Bresee JS, Noel J, et al. Cold weather seasonality of gastroenteritis associated with Norwalklike virus. J. Infect. Dis. 2000;181(Suppl. 2):S284-287.

26. Rha B, Lopman BA, Alcala AN, Riddle MS, Porter CK. Incidence of norovirusassociated medical encounters among active duty United States military personnel and their dependents. Plos One, 2016;11:e0148505.

27. Blacklow NR, Dolin R, Fedson DS, Dupont, $H$, Northrup RS, et al. Acute infectious nonbacterial gastroenterititis: Etiology and pathogenesis. Ann. Intern. Med. 1972;76:993-1008.

28. Dolin R, Levy AG, Wyatt RG, Thronhill TS, Gardner JD. Viral gastroenteritis induced by the Hawaii agent: Journal histopathology and serologic response. Am. J. Med. 1975;59:761-768.

29. Shreiber DS, Blacklow NR, Trier JS. The mucosal lesion of the proximal small intestine in acute infectious nonbacterial gastroenteritis. J. Infect. Dis. 1973;129: 705-708. 
30. Shreiber DS, Blacklow NR, Trier JS. The small intestinal lesion induced by Hawaii agent in acute infectious nonbacterial gastroenteritis. J. Infect. Dis. 1974;129: 705-708.
31. Troger H, Loddenkemper C, Schneider T, Schreier E, Epple H, et al. Structural and functional changes of duodenum in human norovirus infection. Gut. 2009;58:10701077.

(c) 2019 Tripathi and Kumar; This is an Open Access article distributed under the terms of the Creative Commons Attribution License (http://creativecommons.org/licenses/by/4.0), which permits unrestricted use, distribution, and reproduction in any medium, provided the original work is properly cited.

Peer-review history:

The peer review history for this paper can be accessed here: http://www.sdiarticle3.com/review-history/48077 